\title{
ANALISIS YURIDIS PENGAWASAN \\ ASIMILASI DAN INTEGRASI BAGI NARAPIDANA DAN ANAK \\ KETIKA PANDEMI COVID-19 \\ (Studi di Balai Pemasyarakatan Kelas I Malang)
}

\author{
-Enny Umronah-
}

\begin{abstract}
ABSTRAK
Pada masa pandemi Covid-19 Pemerintah melalui Permenkumham, mengeluarkan kebijakan Asimilasi dan integrasi bagi Narapidana Dewasa dan Anak. Penerapan kebijakan ini disertai dengan perangkat pengawasan bagi Narapidana yang mendapat program tersebut. Pengawasan pelaksanaan asimilasi dan integrasi dilaksanakan oleh Balai Pemasyarakatan, dengan petugas pengawas yang disebut dengan Pembimbing Kemasyarakatan (PK). Pengawasan tersebut dilaksanakan dengan cara mengamati dan menilai terhadap pelaksanaan program layanan, pembinaan dan pembimbingan warga binaan pemasyarakatan yang dilakukan secara virtual (Dalam Jaringan). Pengawasan ini sebagai sarana pencegahan dan penanggulanan virus Covid-19, serta agar mereka tidak melakukan pelanggaran hukum kembali. Pengawasan yang tidak terlaksana secara maksimal dapat mengakibatkan pelanggaran hukum kembali para pelaku tindak pidana. Apalagi dalam situasi pandemi pengulangan pelanggaran hukum menjadi sorotan masyarakat, karena menjadikan dampak ganda bagi masyarakat selain dari dampak pandemi. Berdasarkan uraian diatas dalam Karya Tulis Ilmiah ini penulis mengambil judul "Analisis Yuridis Pengawasan Asimilasi dan Integrasi Bagi Narapidana dan Anak ketika Pandemi Covid-19 (Studi di Balai Pemasyarakatan Kelas I Malang)". Penelitian ini memiliki rumusan masalah berupa: bagaimanakah pengawasan asimilasi dan integrasi bagi narapidana dan anak ketika Pandemi Covid-19?, serta faktor-faktor apa yang mempengaruhi pelaksanaan pengawasan?. Selanjutnya penelitian ini bertujuan untuk mendeskripsikan dan menjelaskan pengawasan asimilasi dan Integrasi bagi narapidana dan anak ketika Pandemi Covid-19, serta menguraikan dan menganalisis faktorfaktor yang mempengaruhinya.
\end{abstract}

Kata Kunci : Pengawasan, Asimilasi, Integritas, Narapidana, Anak

\begin{abstract}
During the Covid-19 pandemic the Government through the Ministry of Law and Human Right Regulation, issued an Assimilation Policy and Integration for Adult and Children Inmate. The implementation of this policy is accompanied by a monitoring device for Inmates who receive the program. Supervision of the implementation of assimilation and integration is carried out by the Rehabilitation center (Bapas), with a supervisory officer called the Social Adviser (PK). The supervision is carried out by observing and assessing the implementation of the service program, coaching and mentoring of the prisoners that are conducted by online. This supervision is a means of preventing and controlling the Covid-19 virus, and so that they do not violate the law again. Supervision that is not carried out optimally can result in violations of the law again by the perpetrators of criminal acts. Especially in a pandemic situation, the repetition of violations of the law is in the public spotlight, because it makes a double impact on the community apart from the pandemic impact. Based on the description above in this Scientific Writing, the writer takes the title "Juridical Analysis On The Supervision Of Assimilation And Integration To Adult And Child Inmates During Covid 19 Pandemic (Study At Class 1 Rehabilitation Center Of Malang)". This research has the formulation of the problem in the form of: how was the supervision of assimilation and integration for adult and children inmates during the Covid-19 Pandemic? and what factors influence the implementation of assimilation and integration supervision for inmate parole and integration when the Covid-19 Pandemic? Furthermore, this study aims to describe and explain the supervision of assimilation and integration for adult and children inmates when the Covid-19 Pandemic, also describe and analyze the factors that influence the supervision of assimilation and integration for adult and children inmates during the Covid-19 Pandemic.
\end{abstract}

Keywords: Oversight, Assimilation, Integrity, Prisoners, Children

\section{PENDAHULUAN}

Terjadinya pandemi Virus Corona -19 yang konon berasal dari Kota Wuhan Cina lalu menyebar di Indonesia awal tahun 2020 tidak hanya berdampak pada sisi kesehatan fisik semata, akan tetapi semua aspek kehidupan manusia mendapatkan dampak dimulai dari tatanan kehidupan sosial, politik, ekonomi 
termasuk didalamnya aspek hukum di masyarakat.

COVID-19 yang sangat mudah menular dan menyebar, mengharuskan pemerintah membuat tatanan baru dalam kehidupan di masyarakat. Beberapa peraturan yang melingkupi hajat hidup orang banyak ditetapkan guna mengatur serangkaian teknis pelaksanaan kehidupan di masa pandemi. Demikian juga di Kementerian Hukum dan HAM RI, melalui Peraturan Menteri Hukum RI Nomor 10 Tahun 2020 tentang Syarat Pemberian Asimilasi dan Hak Integrasi Bagi Narapidana dan Anak dalam Rangka Pencegahan dan Penanggulangan Penyebaran Covid-19. Berdasar Permenkumham ini pemerintah membebaskan 35.000 lebih Narapdana di seluruh Indonesia.

Peraturan ini mendapatkan tanggapan pro maupun kontra di masyarakat, akan tetapi diluar daripada itu peraturan ini ditetapkan dalam rangka penanggulangan dan pencegahan penyebaran COVID-19 ditengah kondisi sejumlah penjara yang menampung tahanan melebihi kapasitas yang ada (overcrowding). Keadaan seperti ini yang menyebabkan kebijakan kesehatan seperti Physical Distancing tidak dapat diterapkan di dalam Lapas.

Asimilasi dan integrasi dirumah merupakan sebuah upaya hukum ditengah suasana kedaruratan yang dapat mengancam jiwa seluruh umat manusia dikarenakan Covid19, meskipun masyarakat menilai dengan berbagai tanggapan terkait dengan banyaknya pelanggaran kembali oleh Narapidana, akan tetapi bila dihitung dari jumlah Narapidana Dewasa/Anak yang dikeluarkan dibanding jumlah pelanggaran yang ada sangat kecil. Hal ini sebagaimana Sambutan yang disampaikan Menteri Hukum dan HAM RI, Yasonna Laoly saat memberikan sambutan dalam acara diskusi online bertajuk Pandemi Covid-19 dan Asimilasi Narapidana, Rabu (6/5/2020) bahwa “hingga 20 April 2020, dari total 38.882 narapidana yang menerima asimilasi dan integrasi, sebanyak 50 napi atau 0,12 persen mengulangi tindakan kriminalnya setelah dikeluarkan dari lapas atau rutan, angka ini jauh lebih kecil dibandingkan tingkat residivisme Indonesia secara umum dan di negara-negara lain pada masa biasa".

Pengawasan asimilasi dan integrasi dilaksanakan oleh Balai Pemasyarakatan, dengan petugas pengawas yang disebut dengan Pembimbing Kemasyarakatan (PK). Pengawasan tersebut dilaksanakan dengan cara mengamati dan menilai terhadap pelaksanaan program layanan, pembinaan dan pembimbingan warga binaan pemasyarakatan yang dilakukan secara virtual (Dalam Jaringan). Pengawasan ini sebagai sarana pencegahan dan penanggulanan virus Covid-19, serta agar mereka tidak melakukan pelanggaran hukum kembali.

Pengawasan oleh Pembimbing Kemasyarakatan dilaksanakan secara virtual (dalam jaringan) melalui sarana telekomunikasi Telepon, Video Call ataupun Video Converence. Disatu sisi pengawasan daring ini dapat menjadi sarana penanggulangan penyebaran Covid-19, akan tetapi disisi lainnya pengawasan dalam jaringan ini mengalami berbagai kendala di lapangan, sementara pengawasan asimilasi dirumah yang tidak terlaksana secara maksimal mengakibatkan pelanggaran hukum kembali para pelaku tindak pidana, hal ini mengakibatkan proses penegakan hukum di masyarakat tidak berjalan dengan baik. Berdasarkan latar belakang diatas dalam Karya Tulis Ilmiah ini penulis mengambil judul "Analisis Yuridis Pengawasan Asimilasi dan Integrasi Bagi Narapidana dan Anak ketika Pandemi Covid-19 (Studi di Balai Pemasyarakatan (BAPAS) Kelas I Malang)”.

\section{BAHAN DAN METODE}

Bahan yang digunakan dalam penelitian ini adalah autoritatif. Bahan-bahan hukum autoritatif meliputi peraturan perundangundangan, argument atau pendapat-pendapat penulis dalam buku teks atau bentuk komentar lain tentang bahan hukum baik yang berbentuk cetakan maupun online atau elektronik.

Adapun jenis penelitian yang digunakan adalah yuridis empiris, dengan menitikberatkan 
pada tipe penelitian hukum yuridis empiris (sociological jurisprudence). Penelitian hukum yuridis empiris (sociological jurisprudence) berbasis pada ilmu hukum normatif (peraturan perundangan) tetapi bukan mengkaji mengenai sistem norma dalam aturan perundangan, namun mengamati bagaimana reaksi dan interaksi yang terjadi ketika sistem norma itu bekerja didalam masyarakat. Penelitian ini juga sering disebut sebagai penelitian bekerjanya hukum (law in action) yang mendasarkan pada doktrin para realis Amerika seperti Holmes. ${ }^{1}$

\section{PEMBAHASAN}

\section{A. GAMBARAN UMUM ASIMILASI DAN INTEGRASI}

Dalam Peraturan Menteri Hukum dan Hak Asasi Manusia RI Nomor 41 Tahun 2017 tentang Pelaksanaan Jabatan Fungsional Pembimbing Kemasyarakatan disebutkan bahwa pemasyarakatan memiliki peranan penting dalam sistem hukum di Indonesia untuk mengubah perikehidupan para pelanggar hukum agar dapat kembali ke tengah-tengah masyarakat melalui fungsi reintegrasi. Fungsi ini dilaksanakan melalui program asimilasi, dan integrasi (Pembebasan Bersyarat, Cuti Bersyarat, Cuti Mengunjungi Keluarga dan Cuti Menjelang Bebas).

Asimilasi menurut Peraturan Menteri Hukum dan HAM RI Nomor 03 Tahun 2018 bahwa Asimilasi adalah proses pembinaan Narapidana dan Anak yang dilaksanakan dengan membaurkan Narapidana dan Anak dalam kehidupan masyarakat. Dalam hal ini asimilasi merupakan proses sosial antara pelaku pelanggar hukum dengan kelompok sosial tertentu dengan tujuan agar secara individu mereka dapat melebur dan menyesuaikan budaya kelompoknya. Terdapat tujuh tingkatan asimilasi menurut Milton M. Gordon (1968) yang dikutip oleh Poerwanti Hadi Pratiwi, yaitu :

Satjipto Rahardjo, Paradigma Hukum Indonesia Perpektif Sejarah, makalah disampaikan pada Simposium Nasional Ilmu Hukum Program Doktor, (Semarang, 1998), hlm 1-2
1. Asimilasi budaya atau perilaku (cultural or behavioral assimilation), berhubungan dengan perubahan pola kebudayaan guna menyesuaikan diri dengan kelompok mayoritas.

2. Asimilasi struktural (structural assimilation); berkaitan dengan masuknya kelompok minoritas secara besar-besaran ke dalam klik, perkumpulan, dan pranata pada tingkat kelompok primer dari golongan mayoritas

3. Asimilasi perkawinan (marital assimilation), berkaitan dengan perkawinan antargolongan secara besar-basaran

4. Asimilasi identifikasi (identificational assimilation); berkaitan dengan kemajuan rasa kebangsaan secara eksklusif berdasarkan kelompok mayoritas

5. Asimilasi penerimaan sikap (attitude receptional assimilation); menyangkut tidak adanya prasangka (prejudice) dari kelompok mayoritas.

6. Asimilasi penerimaan perilaku (behavior receptional assimilation); ditandai dengan tidak adanya diskriminasi dari kelompok mayoritas.

7. Asimilasi kewarganegaraan (civic assimilation), berkaitan dengan tidak adanya perbenturan atau konflik nilai dan kekuasaan dengan kelompok mayoritas.

Dalam hal Asimilasi dirumah, maka proses peleburan itu dilaksanakan oleh para pelaku pelanggar hukum kedalam anggota keluarganya dirumah, agar mereka menyesuaikan kembali dan berinteraksi sosial lebih baik dengan aturan keluarga yang ada, serta tidak membuat perilaku yang menimbulkan masalah hukum kembali. Proses sosial tersebut dilakukan dengan meleburkan budaya, identifikasi, penerimaan sikap dan penerimaan perilaku sehingga para pelanggar hukum tidak menampilkan perilaku yang berbeda dengan aturan atau norma yang ada.

Selanjutnya dalam Peraturan Pemerintah Nomor 31 Tahun 1999 tentang Pembinaan dan Pembimbingan Warga Binaan Pemasyarakatan, Integrasi didefinisikan sebagai pemulihan kesatuan hubungan hidup, kehidupan dan 
penghidupan Narapidana dan Anak Didik Pemasyarakatan dengan masyarakat.

Mengutip pendapat Clemens Bartolas (Dalam Andi Wijaya Rivai, 2014), dalam melaksanakan integrasi pelanggar hukum terdapat asumsi yang mendasarinya :

“... tiga asumsi dasar dalam model reintegrasi yaitu:

1) Permasalahan yang menyangkut pelaku kejahatan harus dipecahkan bersama dengan masyarakat tempat mereka berasal.

2) Masyarakat mempunyai tanggung jawab terhadap masalah yang terjadi menyangkut pelaku kejahatan dan tanggung jawab masyarakat dapat ditunjukkan dengan membantu pelanggar hukum tersebut untuk dapat mematuhi hukum yang telah ditetapkan. Oleh karena itu, masyarakat harus memberikan kesempatan kepada pelaku kejahatan untuk mengembangkan perilaku yang taat hukum, dan pelaku kejahatan harus belajar untuk memanfaatkan kesempatan tersebut.

3) Kontak dengan masyarakat bertujuan untuk mencapai tujuan dari reintegrasi itu sendiri. Pelaku kajahatan harus didekatkan dengan peran-peran normal sebagai warga masyarakat, anggota keluarga, dan pekerja."

Bahwa dalam mengintegrasikan pelanggar hukum kedalam derap kehidupan masyarakat, perlu memperhatikan tahap-tahap sebagai berikut:

Model reintegrasi yang ideal harus mengandung empat tahap:

1) Prison based rehabilitation;

2) Transitional service;

3) Community after care; dan

4) Postsupervision certification as "normal";

"Konsep reintegrasi tidak dapat dipisahkan dengan konsep communitybased corrections. Logika pembenaran konsep community based corrections adalah bahwa masyarakat merupakan tempat yang paling ideal untuk melakukan upaya pembinaan pelanggar hukum". ${ }^{2}$

Dalam pengertian tersebut integrasi kedalam masyarakat menjadi sebuah proses agar para pelanggar hukum menjadi pulih kehidupannya, menjalankan peran normal di masyarakat, dan keberadaan masyarakat dapat membantu dirinya taat terhadap hukum.

\section{B. ANALISIS YURIDIS PENGAWASAN ASIMILADI DAN INTEGRASI BAGI NARAPIDANA DAN ANAK KETIKA PANDEMI COVID-19 (Studi di Balai Pemasyarakatan Kelas I Malang)}

Analisis Yuridis Pengawasan Asimiladi Dan Integrasi Bagi Narapidana Dan Anak Ketika Pandemi Covid-19 meliputi variabelvariabel berikut ini, yaitu:

1. Peraturan Perundang-undangan yang mengaturnya;

2. Pelaksanaan Tugas dan Peran Pembimbingan Kemasyarakatan;

3. Pihak-pihak yang terkait dengan Pengawasan Asimilasi dan Integrasi;

4. Pelaksanaan Pengawasan Asimilasi dan Integrasi bagi Narapidana dan Anak Ketika Pandemi Covid-19.

Selanjutnya dalam tulisan ini, dapat diketahui dan diuraikan pembahasannya sebagai berikut :

1. Peraturan Perundang-undangan yang mengatur Pengawasan Narapidana dan Anak sebelum pandemi Covid-19

Beberapa peraturan yang mengatur tentang pengawasan asimilasi dan integrasi sebelum terjadinya pandemi adalah sebagai berikut :

a. Undang-undang Republik Indonesia Nomor 12 tahun 1995 tentang Pemasyarakatan.

Dalam Undang-undang ini peran pengawasan Bapas belum disebutkan secara khusus, peran pengawasan yang ada masih

${ }^{2}$ Andi Wijaya Rivai, Op.Cit., , hlm.20 
baru dilakukan terhadap anak. Bapas disebutkan sebagai pranata untuk melaksanakan bimbingan Klien Pemasyarakatan. Dalam hal melaksanakan bimbingan ini, Bapas melaksanakan pengawasan terhadap orang tua asuh atau badan sosial dan orang tua atau wali yang diserahi anak agar kewajiban sebagai pengasuh dapat dipenuhi serta melakukan pemantapan terhadap perkembangan anak yang diasuh.

b. Undang-Undang RI Nomor 11 Tahun 2012 tentang Sistem Peradilan Pidana Anak.

Maksud dari pengawasan didalam Undang-undang ini disebutkan dalam pasal 1 ayat (23) berbunyi "Klien Anak adalah Anak yang berada didalam pelayanan, pembimbingan, pengawasan, dan pendampingan Pembimbing Kemasyarakatan", begitu pula dalam pasal 65 disebutkan bahwa Pembimbing Kemasyarakatan bertugas melakukan pendampingan, pembimbingan, dan pengawasan terhadap Anak yang memperoleh asimilasi, pembebasan bersyarat, cuti menjelang bebas dan cuti bersyarat.

c. Peraturan Pemerintah Republik Indonesia Nomor 32 Tahun 1999 sebagaimana telah dilakukan perubahan kedua dengan Peraturan Pemerintah Republik Indonesia Nomor 99 Tahun 2012 tentang tentang Syarat dan Tata Cara Pelaksanaan Hak Warga Binaan Pemasyarakatan.

Dalam peraturan ini asimilasi narapidana dan anak dilakukan pembimbingan oleh Bapas (Pasal 38), serta pembimbingan dan pengawasan integrasi (Pembebasan Bersyarat, Cuti Mengunjungi Keluarga, Cuti Menjelang bebas, dilaksanakan juga oleh Bapas baik secara perseorangan maupun kelompok secara berkala dan berkesinambungan (Pasal 42, 45, 50). Pengertian pengawasan yang dilaksanakan Bapas masih tergabung dengan pengertian pembimbingan yaitu pemberian tuntunan untuk meningkatkan kualitas ketaqwaan terhadap Tuhan Yang Maha Esa, intelektual, sikap dan perilaku, professional, kesehatan jasmani dan rohanis klien pemasyarakatan.

d. Peraturan Pemerintah Republik Indonesia Nomor 31 Tahun 1999 tentang Pembinaan dan Pembimbingan.

Dalam pasal 36 disebutkan bahwa bimbingan dan pengawasan klien dilaksanakan oleh Pembimbing Kemasyarakatan pada Bapas, serta pengawasan terhadap orang tua asuh atau badan sosial dan orang tua atau wali untuk memenuhi kewajiban pengasuhan terhadap anak. Bimbingan dan pengawasan ini dilakukan terhadap narapidana dan anak yang menjalani integrasi (pasal 35).

e. Peraturan Menteri Hukum dan Hak Asasi Manusia RI Nomor : 41 Tahun 2017 Tentang Pelaksanaan Jabatan Fungsional Pembimbing Kemasyarakatan.

Pembimbing Kemasyarakatan diatur dalam peraturan ini memiliki posisi yang strategis sejak praajudikasi, ajudikasi dan post ajudikasi, begitu pula dalam proses peradilan anak Pembimbing Kemasyarakatan secara factual hadir diseluruh fase proses peradilan guna memberikan rekomendasi terbaik dalam penanganan Anak yang berhadapan dengan Hukum. Dalam pelaksanaan tugas tersebut Pembimbing Kemasyarakatan melaksanakan penelitian kemasyarakatan, pendampingan, pembimbingan dan pengawasan terhadap klien pemasyarakatan.

f. Peraturan Menteri Hukum dan HAM RI Nomor 03 tahun 2018 dan perubahannya Nomor 18 Tahun 2019, tentang Syarat dan Tata Cara Pemberian Remisi, Assimilasi, Cuti Mengunjungi Keluarga, Pembebasan Bersayarat, Cuti Menjelang Bebas dan Cuti Bersyarat.

Didalam peraturan ini asimilasi dimaksudkan sebagai proses pembinaan narapidana dan anak yang dilaksanakan dengan membaurkan narapidana dan anak dalam kehidupan masyarakat. Sedangkan integrasi kedalam kehidupan masyarakat dilaksanakan dalam bentuk Pembebasan Bersyarat, Cuti Menjelang Bebas, dan Cuti Bersyarat. 
g. Peraturan Menteri Pendayagunaan Aparatur Negara dan Reformasi Birokrasi Nomor 22 Tahun 2016 tentang Jabatan Fungsional Pembimbing Kemasyarakatan.

Pengawasan merupakan bagian yang tidak terpisahkan dalam bimbingan kemasyarakatan, karena peraturan ini menegaskan bahwa bimbingan kemasyarakatan adalah kegiatan yang dilakukan oleh Pembimbing Kemasyarakatan dalam menangani klien pemasyarakatan, yang meliputi penelitian kemasyarakatan, pendampingan, pembimbingan, pengawasan dan sidang tim pengamat pemasyarakaran.

Kegiatan pengawasan yang dimaksud adalah meliputi pengawasan terhadap anak dalam proses diversi, penetapan hasil diversi atau putusan hakim, juga pengawasan terhadap narapidana meliputi pengawasan putusan hakim, pengawasan dalam pelaksanaan program perawatan dan layanan tahanan anak dan dewasa, pengawasan program pembinaan anak di LPKA dan pembinaan narapidana dewasa di Lapas atau Rutan, pengawasan pembimbingan klien anak dan klien dewasa berdasarkan hadil rekomendasi penelitian kemasyarakatan, pengawasan terhadap klien yang meminta izin keluar negeri, dan pengawasan program bimbingan yang mendapatkan izin keluar negeri, melakukan pencabutan asimilasi dan integrasi bagi yang melanggar.

h. Keputusan Direktur Jenderal Pemasyarakatan Nomor : PAS-208. PK.01.05.10 Tahun 2016 tentang Pedoman Umum Pengawasan Klien Pemasyarakatan.

Pedoman ini mengatur tentang pengawasan dapat dilakukan setelah adanya rekomendasi Litmas, Program Bimbingan atau Penetapan Pengadilan / Putusan Hakim. Rekomendasi Litmas yang dimaksud meliputi: litmas layanan tahanan, litmas awal pembinaan, asimilasi dan pembimbingan luar lembaga (asimilasi lingkungan Lapas, asimilasi pihak ketiga, asimilasi lapas terbuka dan cuti mengunjungi keluarga), integrasi (pembebasan bersyarat, cuti menjelang bebas, dan cuti bersyarat). Sedangkan program bimbingan lainnya meliputi Ijin keluar negeri /keluar kota, dan Penetapan / putusan hakim meliput diversi, diserahkan ke Panti Sosial / Organisasi Masyarakat, Panti Rehabilitasi / Yayasan Keagamaan, Pidana Bersyarat, Pidana Pengawasan.

Beberapa peraturan yang mengatur tentang pengawasan asimilasi dan integrasi setelah pandemi adalah sebagai berikut :

a. Peraturan Menteri Hukum Dan Hak Asasi

Manusia Republik Indonesia Nomor 10

Tahun 2020 Tentang Syarat Pemberian

Asimilasi Dan Hak Integrasi Bagi

Narapidana Dan Anak Dalam Rangka

Pencegahan Dan Penanggulangan

Penyebaran Covid-19;

Peraturan ini ditetapkan sehubungan dengan tingkat hunian Lapas/Rutan yang sangat rentan terhadap penyebaran dan penularan Covid-19 sehingga diperlukan penyelamatan terhadap narapidana dan anak berupa pemberian asimilasi dan integrasi narapidana selain yang ditetap dalam PP Nomor 99 Tahun 2012, dengan telah menjalani $1 / 2$ masa pidana untuk asimilasi narapidana dan paling singkat 3 bulan untuk anak, serta telah menjalani $2 / 3$ untuk integrasi narapidana dan $1 / 2$ untuk integrasi anak sampai tanggal 31 Desember 2020. Asimilasi dan Integrasi ini dilaksanakan dirumah dengan Kepala Bapas bertanggung jawab terhadap pembimbingan dan pengawasannya.

b. Keputusan Menteri Hukum Dan Hak Asasi

Manusia Republik Indonesia Nomor M.HH-19.PK.01.04.04 Tahun 2020

Tentang Pengeluaran dan Pembebasan Narapidana dan Anak melalui Asimilasi dan Integrasi Dalam Rangka Pencegahan dan Penanggulangan Penyebaran Covid19.

Bahwa dalam keputusan ini disebutkan tentang pembimbingan dan pengawasan asimilasi dan integrasi dilaksanakan oleh Bapas, dengan laporan pembimbingan dan pengawasan dilakukan secara daring.
c. Instruksi
Direktur
Jenderal
Pemasyarakatan Nomor:
PAS- 
08.OT.02.02 Tahun 2020 tanggal 17 Maret 2020 tentang Pencegahan, Penanganan, Pengendalian dan Pemulihan COVID-19 pada Unit Pelaksanaan Teknis Pemasyarakatan.

Intruksi ini mengenai upaya pencegahan, penenganan dan pengendalian di berbagai zona merah, kuning dan hijau
d.
Direktur

Surat Edaran
Pemasyarakatan
PK.01.04.06 T Nomor

Jenderal

PK.01.04.06 Tahun 2020 Tentang

Mekanisme Pelaksanaan Peraturan

Menteri Hukum Dan Hak Asasi Manusia

Nomor 10 Tahun 2020 Tentang Syarat

Pemberian Asimilasi Dan Hak Integrasi

Bagi Narapidana Dan Anak Dalam Rangka

Pencegahan Dan Penanggulangan

Penyebaran Covid-19.

Edaran ini sebagai acuan Kepala Unit Pelaksana Teknis asimilasi dan integrasi rangka pencegahan dan penanggulangan penyebaran Covid-19 dilaksanakan, dengan menunjuk Pembimbing Kemasyarakatan melaksanakan pembimbingan dan pengawasan secara daring.

e. Surat Edaran Direktur Jenderal Pemasyarakatan Nomor:

PAS.497.PK.01.04.04 Tahun 2020 tanggal

31 Maret 2020 tentang Pengeluaran dan Pembebasan Narapidana dan Anak melalui Asimilasi dan Integrasi dalam rangka Pencegahan dan Penanggulangan Penyebaran Covid-19.

Edaran ini memberikan petunjuk tentang pelaksanaan pengeluaran dan pembebasan narapidana dan anak melalui asimilasi dan integraso dalam rangka pencegahan dan penanggulangan penyebaran Covid-19.

f. Surat Edaran Direktur Jenderal Pemasyarakatan Nomor: PAS.20.PR.01.01 Tahun 2020 tanggal 26 Maret 2020 tentang Langkah Progresif dalam Penanggulangan Penyebaran COVID-10 pada UPT Pemasyarakatan.

Edaran ini mengenai langkah progresif setiap UPT pemasyarakatan agar tetap selaras dengan penyelenggaraan tugas dan fungsi pemasyarakatan dalam menanggulangi Covid19.

g. Surat Perintah Direktur Jenderal

Pemasyarakatan Nomor: PAS.KP.04.01.69 tanggal 9 April 2020.

Surat ini berisi tentang pelaksanaan pengeluaran dan pembebasan narapidan dan anak melalui asimilasi dan integrasi dalam rangka pencegahan dan penanggulangan penyebaran covid-19.

h. Pedoman Pelaksanaan Direktur Jenderal Pemasyarakatan Tahun 2020 Tentang Pedoman Pelaksanaan Penelitian Kemasyarakatan dan Pendampingan secara Daring serta Pembimbingan dan Pengawasan Klien Asimilasi dan Integrasi dalam Rangka Pencegahan \& Penanggulangan Penyebaran Covid-19.

Dalam pedoman pelaksanaan ini mengatur tentang pembimbingan dan pengawasan selama masa pandemi dan aturan pelaksanaannya.

\section{Pelaksanaan Tugas dan Peran Pembimbingan Kemasyarakatan}

Pejabat fungsional Pembimbing Kemasyarakatan (PK) adalah PNS yang diberikan tugas, tanggung jawab, dan wewenang untuk melaksanakan kegiatan di bidang bimbingan kemasyarakatan, hal ini tertuang dalam Peraturan Menteri Hukum dan Ham Nomor 41 Tahun 2017. Sedangkan pengertian PK berdasarkan Undang-undang Nomor 11 Tahun 2012 Tentang SPPA sebagaimana disebutkan dalam Pasal 1 angka 13, yakni Pembimbing Kemasyarakatan adalah "pejabat fungsional penegak hukum yang melaksanakan penelitian kemasyarakatan, pembimbingan, pengawasan, dan pendampingan terhadap anak di dalam dan di luar proses peradilan pidana" dengan tugas melaksanakan kegiatan di bidang bimbingan kemasyarakatan.

Pengeluaran narapidana dan anak dalam penanggulangan covid-19 melalui program asimilasi dan integrasi ini mempersyaratkan Pembimbing Kemasyarakatan yang akan memberikan pembimbingan dan pengawasan secara daring. Pengawasan secara daring yang 
dilakukan oleh PK dengan mengoptimalkan sarana berbasis teknologi informasi dengan cara menghubungi klien menggunakan media telpon / sms / whatsapp / videocall sesuai jadwal untuk menyampaikan materi bimbingan sekaligus melakukan pengawasan

\section{Pihak-pihak yang terkait dengan}

\section{Pengawasan Asimilasi dan Integrasi}

a. Keluarga Klien;

b. Petugas

Lapas/LPKA/Rutan (Wali/Pengasuh);

c. Kelompok Masyarakat disekitar tempat tinggal;

d. Pamong setempat;

e. Pemerintah Daerah setempat;

f. Aparat Penegak Hukum terkait.
4. Pelaksanaan Pengawasan Asimilasi dan Integrasi bagi Narapidana dan Anak Ketika Pandemi Covid-19.

Dalam pedoman pelaksanaan pengawasan dalam rangka pencegahan dan penanggulangan penyebaran covid-19 yang dikeluarkan oleh Direktorat Jenderal Pemasyarakatan dibuat bersama-sama dengan pelaksanaan penelitian kemasayarakatan, pendampingan, pembimbingan yang semuanya dilakukan secara Daring. Dalam hal pengawasan terhadap narapidana dan anak sangat terkait dengan pembimbingan yang telah dilaksanakan oleh Pembimbing Kemasyarakatan (PK).

Gambar 1.

Pedoman Pelaksanaan Pengawasan Daring

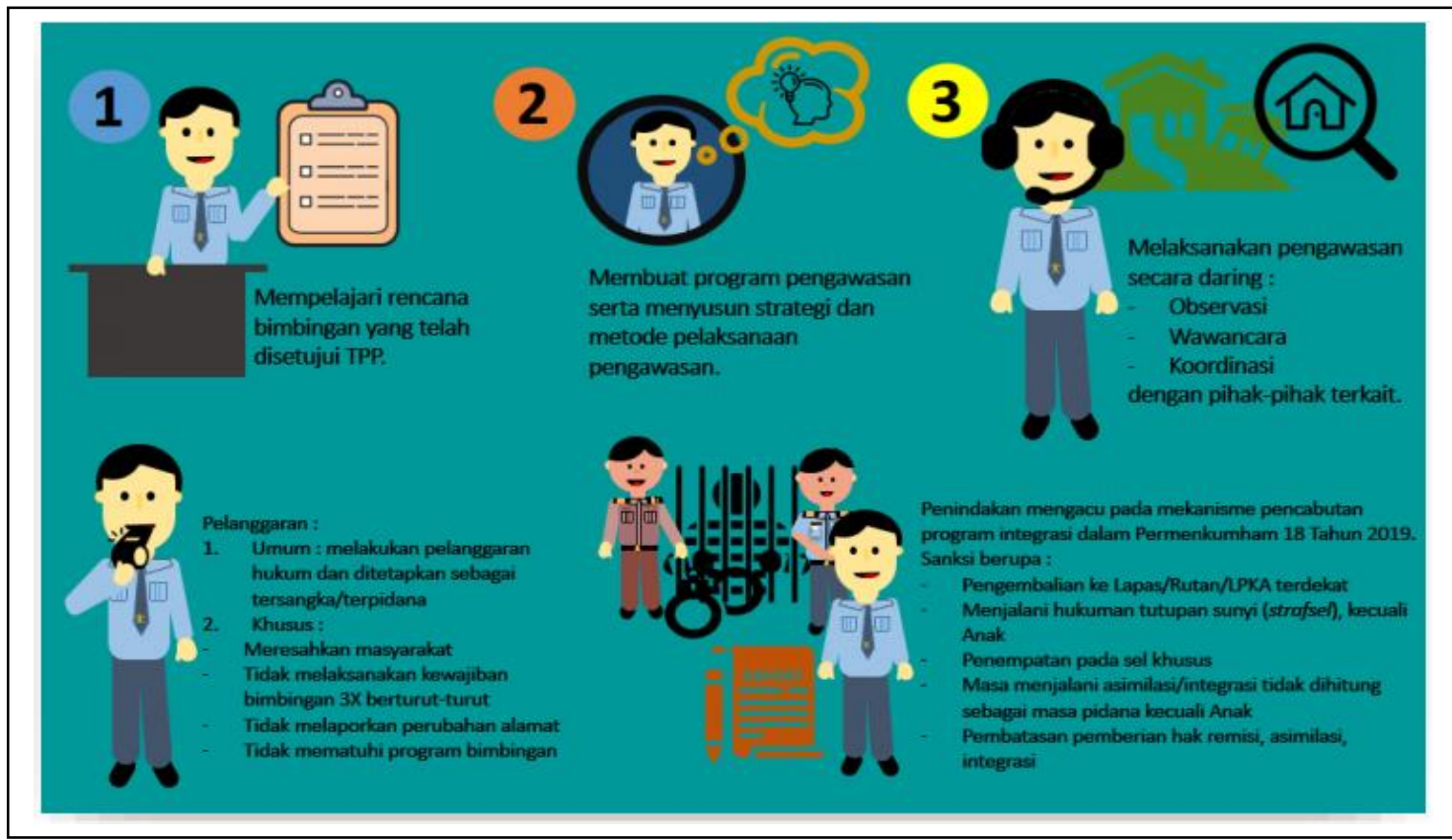

Sumber Gambar : Pedoman Pelaksanaan Penelitian Kemasyarakatan dan Pendampingan secara Daring serta Pembimbingan dan Pengawasan Klien Asimilasi dan Integrasi dalam Rangka Pencegahan \& Penanggulangan Penyebaran Covid-19, 2020, Direktorat Jenderal Pemasyarakatan

Didalam gambar pengawasan klien Asimilasi dan Integrasi yang dikeluarkan oleh Direktorat Jenderal Pemasyarakatan, dapat diuraikan sebagai berikut :

1. Kegiatan pengawasan yang pertama kali dilakukan adalah membuat Perencanaan. Perencanaan pengawasan ini meliputi : a. Mempelajari rencana bimbingan yang ditelah disetujui oleh Tim Pengamat Pemasyarakatan Bapas. Sehingga para PK hendaknya memastikan bahwa masingmasing klien asimilasi telah dibuatkan rencana bimbingannya.

b. Selanjutnya kegiatan berikutnya adalam membuat program pengawasan yang 
disesuaikan dengan program bimbingan yang telah ditetapkan. Dalam hal ini PK menyusun programnya, sehingga pengawasan yang dilakukan menjadi terarah.

c. Menetapkan strategi dan metode yang tepat dalam melaksanakan pengawasan, diantaranya adalah observasi langsung keadaan klien dan lingkungan sekitarnya, termasuk pihak-pihak yang terlibat secara daring, kemudian wawancara kepada klien dan pihak-pihak yang terlibat dengan menyampaikan beberapa pertanyaan yang terkait pembimbingan dan informasi perkembangan bimbingannya secara daring, kemudian melakukan koordinasi untuk memastikan pihak-pihak yang terkait melakukan peran sesuai dengan program pembimbingan secara daring.

d. Membuat perencanaan waktu pengawasan, dalam hal ini sebagaimana Edaran Direktur Jenderal Nomor PAS-516. PK.01.04.06 Tahun 2020 menyebutkan bahwa "Menunjuk pembimbing kemasyarakatan untuk melaksanakan pembimbingan dan pengawasan secara daring dengan tahapan: a) Menyusun jadwal pelaksanaan pembimbingan dan pengawasan, paling sedikit 1 (satu) minggu sekali untuk asimilasi dan 1 (satu) bulan sekali untuk integrasi”. Perencanaan waktu ini yang kemudian dijadikan dasar bagi PK untuk melaksanakan tugas pengawasan secara daring.

e. Menentukan pihak-pihak yang terlibat dalam program pengawasan klien yang disesuakan dengan rencana bimbingan secara daring, diantaranta keluarga klien, petugas Lapas/Rutan (Wali Pengasuh), kelompok masyarakat sekitar tempat tinggal klien, pamong setempat, pemerintah daerah setempat, dan Aparat Penegak Hukum Terkait.

f. Menetapkan target pengawasan. Target pengawasan ini ditetapkan berhubungan dengan dasar dilakukan pengeluaran narapidana dan anak dalam asimilasi dan integrasi ini, yaitu agar mereka "Tetap berada di rumah, menjaga kesehatan sesuai dengan standar kesehatan dari pemerintah, tidak melanggar hukum (memenuhi ketentuan syarat umum asimilasi dan integrasi), mematuhi ketentuan syarat khusus asimilasi dan integrasi; dan membantu pemerintah dalam penanggulangan Covid-19".

2. Kegiatan kedua adalah melakukan pengawasan terhadap klien secara daring, meliputi :

a. Melaksanakan pengawasan terhadap klien secara daring selama masa kedaruratan terhadap penanggulangan Covid-19. Pengawasan yang dilakukan secara daring dilakukan dengan mengoptimalkan sarana berbasis teknologi informasi dengan cara menghubungi klien menggunakan media telpon / sms / whatsapp / videocall sesuai jadwal untuk menyampaikan materi bimbingan sekaligus melakukan pengawasan;

b. Bentuk pengawasan secara daring adalah memastikan keberadaan klien dirumah masing-masing, memastikan aktivitas sehari-hari / program bimbingan klien dilaksanakan, memastikan hubungan dengan keluarga dan lingkungan dalam keadaan baik, serta klien dalam keadaan sehat.

c. PK melakukan koordinasi dengan pihak terkait disesuaikan dengan perencanaan yang telah dibuat.

d. PK memberikan laporan pengawasan yang disampaikan kepada Kepala Bapas, dengan cara mengisi catatan hasil bimbingan klien, daftar hadir bimbingan klien dan laporan pengawasan klien.

3. Apabila terjadi pelanggaran dalam asimilasi dan integrasi maka narapidana dan anak dapat dicabut keputusan asimilasi dan integrasinya. Pelanggaran yang dapat menyebabkan dicabutnya program ini adalah :

a. Klien melakukan pelanggaran syarat umum, yaitu pelanggaran hukum yang dilakukan oleh klien asimilasi dan 
integrasi yang ditetapkan sebagai tersangka / terpidana.

b. Klien melakukan pelanggaran syarat khusus, yaitu telah menimbulkan keresahan dalam masyarakat, tidak melaksanakan kewajiban melapor kepada Bapas yang membimbing paling banyak 3 (tiga) kali berturut-turut, tidak melaporkan perubahan alamat atau tempat tinggal kepada Bapas yang membimbing; tidak mengikuti atau mematuhi program pembimbingan yang ditetapkan oleh Bapas (tidak berada di dalam rumah).

4. Setelah terjadinya pelanggaran, maka akan dilakukan penindakan. Penindakan dilakukan berupa : peningkatan program bimbingan, pencabutan program asimilasi sesuai Surat Edaran Direktur Jenderal Pemasyarakatan Nomor PAS- 19 516.PK.01.04.06 Tahun 2020, dengan mekanisme :

a. Kepala Bapas melakukan pencabutan sementara pelaksanaan asimilasi berdasarkan rekomendasi sidang TPP terhadap laporan hasil pengawasan;

b. Kepala Bapas melaporkan dan mengusulkan penetapan pencabutan asimilasi ke Kalapas dengan melampirkan data dukung pelanggaran dan surat keputusan pencabutan sementara;

c. Kepala Lapas menetapkan keputusan pencabutan asimilasi;

d. Kepala Bapas melakukan koordinasi dengan kepolisian dan kejaksaan setempat dalam hal pengembalian Klien ke Lapas/LPKA/Rutan.

5. Sedangkan pencabutan program integrasi dilakukan dengan mekanisme sesuai Peraturan Menteri Hukum RI Nomor 18 Tahun 2019 Tentang Perubahan Atas Permenkumham No 3 tahun 2018 tentang Syarat dan Tata Cara Pemberian Remisi, Asimilasi, CMK, PB, CMB, dan CB.

6. Pemberian sanksi terhadap klien asimilasi dan integrasi dilakukan dengan cara mengembalikan ke Lapas/LPKA/Rutan terdekat, dan berkoordinasi dengan pihak kepolisian, menjalani hukuman tutupan sunyi (strafsel), kecuali untuk Anak, Menempatkan Narapidana dan Anak tersebut pada sel khusus untuk menghindari penyebaran Covid-19 dari luar sesuai dengan Pedoman Penanganan Covid-19, masa menjalani asimilasi atau integrasi tidak dihitung sebagai menjalani masa pidana kecuali Anak, melakukan pembatasan pemberian hak-hak remisi, asimilasi dan integrasi.

Dalam pengawasan asimilasi dan integrasi ini, setiap klien akan dibimbing dan diawasi oleh Pembimbing Kemasyarakatan masing-masing. Interaksi yang intensif dalam masa bimbingan asimilasi yang dilaksanakan 1 kali dalam seminggu dan untuk integrasi dilaksanakan 1 kali dalam sebulan antara klien dan PK akan menimbulkan kedekatan dan meningkatkan kepercayaan klien terhadap PK.

Pembimbing Kemasyarakatan dalam membimbing dan mengawasi klien secara daring harus dibekali dengan berbagai macam keterampilan dan pendekatan, diantaranya adalah keterampilan observasi, wawancara, menjalin relasi, penerimaan, tidak menghakimi, memotivasi dan mendorong klien agar dapat diarahkan sesuai dengan program rencana pembimbingan dan pengawasan dalam pengeluaran narapidana dan anak

C. FAKTOR - FAKTOR YANG MEMPENGARUHI PENGAWASAN ASIMILASI DAN INTEGRASI KETIKA PANDEMI COVID-19.

Faktor-faktor yang mempengaruhi pengawasan asimilasi dan integrasi ketika pandemi covid-19 adalah sebagai berikut :

1. Klien

Data klien yang dikeluarkan dari Lapas/Rutan melalui program asimilasi di Bapas Kelas I Malang pada akhir Bulan Mei 2020 berjumlah 835 orang narapidana dan anak, seperti terlihat dalam tabel berikut :

Tabel 1

Jumlah Klien Asimilasi dan Integrasi Bulan Mei 2020 


\begin{tabular}{|c|l|c|c|c|}
\hline No & Status Klien & Narapidana & Anak & Jumlah \\
\hline 1 & Asimilasi & 822 & 13 & 835 \\
\hline 2 & Integrasi & 1.839 & 19 & 1.858 \\
\hline \multicolumn{2}{|c|}{ JUMLAH } & $\mathbf{2 . 6 6 1}$ & $\mathbf{3 2}$ & $\mathbf{2 . 6 9 3}$ \\
\hline
\end{tabular}

Jumlah klien akan memperngaruhi pengawasan yang dilakukan, selain itu kesediaan dilakukan pembimbingan, kesiapan klien berada ditengah-tengah keluarga, kesiapan menjalankan kewajiban melapor, sikap penerimaan klien terhadap petugas, kondisi ekonomi dan latar belakang masalah serta kondisi budaya setempat.

2. SDM Pembimbing Kemasyarakatan (PK);

Tabel 2

Jumlah Pegawai dan PK Bapas Malang Bulan Mei 2020

\begin{tabular}{|c|l|c|}
\hline No & Statud Pegawai & Jumlah \\
\hline 1 & Struktural & 13 \\
\hline 2 & JFU (staf) & 9 \\
\hline 3 & JFT (PK) & 29 \\
\hline & JUMLAH & $\mathbf{5 1}$ \\
\hline
\end{tabular}

Pada tabel 2 terlihat bahwa jumlah SDM PK adalah 29 orang, rasio asimilasi 1:28 (setiap seminggu sekali masing-masing PK membimbing dan mengawasi 28 klien), sedangkan rasio integrasi 1:64 (setiap sebulan sekali masing-masing PK membimbing dan mengawasi 64 klien), hal ini menandakan masih tingginya rasio pembimbingan dan pengawasan yang harus dilaksanakan oleh masing-masing PK.

3. Pengeluaran narapidana dan anak tidak didasarkan atas penelitian kemasyarakatan dan asesmen resiko residivis (RRI) dan Faktor Kriminogenik.

Hal ini menjadikan pembimbingan dan pengawasan yang dilakukan PK minim data, kurang terjalin kedekatan dengan klien, yang berakibat pada kepatuhan klien menepati jadwal pembimbingan dan pengawasan.

4. Pemanfaatan teknologi dan informasi;

Kemampuan PK dan klien dalam memanfaatkan teknologi informasi sangat mempengaruhi keberhasilan pembimbingan dan pengawasan secara daring. Disisi lain faktor ekonomi mempengaruhi kemampuan klien dalam kepemilikan gadget (Handphone android), ketiadaan pihak-pihak yang terkait yang dapat mendukung daring, keterbatasan data dukung klien seperti keakuratan nomor telepon dan domisili klien, dan informasi laporan pembinaan yang tidak diterima secara utuh oleh Bapas adalah hal-hal yang dapat menjadi faktor penghambat dalam pengawasan daring,

5. Pengelolaan Administrasi klien

Pengelolaan administrasi seperti penyerahan klien dilakukan secara daring dan berkas pendukung data klien terbatas menyebabkan klien tidak teregistrasi secara akurat.

6. Zona merah di Malang Raya;

Beberapa klien yang tidak dapat dihubungi menjadi tidak dapat ditelusuri keberadaannya secara langsung, karena wilayah kerja yang luas dan berada dalam zona merah penanggulangan Covid-19.

\section{KESIMPULAN}

Berdasarkan uraian hasil pembahasan di atas, dapat dibuat kesimpulan sebagai berikut :

1. Analisis Yuridis Pengawasan Asimiladi

Dan Integrasi Bagi Narapidana Dan Anak Ketika Pandemi Covid-19 (Studi Di Balai Pemasyarakatan Kelas I Malang)

Bahwa peraturan asimilasi dan integrasi dalam masa pandemi dibuat sebagai penanggulangan kedaruratan Covid-19 yang tidak dapat dihadapi dalam situasi Lapas/Rutan yang Overcrowded, oleh karena itu aturan dibuat sedemikian rupa dengan tetap memperhatikan keamanan dan protokol kesehatan.

\section{Faktor - Faktor Yang Mempengaruhi} Pengawasan Asimilasi Dan Integrasi Ketika Pandemi Covid-19.

Faktor - faktor yang mempengaruhi pelaksanaan pengawasan diantaranya adalah klien baik secara jumlah maupun kesiapan menjalani pembimbingan dan pengawasan, kapasitas SDM PK yang terbatas, pengeluaran 
narapidana dan anak tidak didasarkan atas penelitian kemasyarakatan dan asesmen resiko residivis (RRI) dan Faktor Kriminogenik, pemanfaatan teknologi dan informasi, pengelolaan administrasi dan zona merah covid-19.

\section{SARAN}

Saran yang dapat penulis ajukan dari hasil penelitian ini, untuk sempurnanya pelaksanaan pembimbingan klien pemasyarakatan adalah :

1. Didalam Peraturan Menteri Hukum dan HAM RI Nomor 10 Tahun 2020 ketiadaan syarat Penelitian Kemasyarakatan dalam asimilasi dan integrasi menjadi kendala tersendiri dalam pembimbingan dan pengawasan. Oleh karena itu perlu adanya persyaratan asesmen RRI dan Faktor Kriminogenik sebelum dilakukan pengeluaran sehingga dapat diketahui tentang tingkat risiko residivis dan faktor kriminogenik narapidana dan anak;

2. Tahap asesmen RRI dan Faktor Kriminogenik akan membantu PK dalam melaksanakan pembimbingan dan pengawasan daring;

3. Perlunya kelengkapan data dukung klien dalam pengeluaran narapidana dan anak asimilasi dan integrasi yang akan memudahkan dalam pembimbingan dan pengawasan klien;

\section{DAFTAR PUSTAKA}

\section{Buku :}

Direktorat Jenderal Pemasyarakatan, 2020, Pedoman Pelaksanaan Penelitian Kemasyarakatan dan Pendampingan secara Daring serta Pembimbingan dan Pengawasan Klien Asimilasi dan Integrasi dalam Rangka Pencegahan \& Penanggulangan Penyebaran Covid-19. Jakarta

Fadjar, Mukthie. 2012. Kapita Selekta, Teori

Hukum, Universitas Widya Gama Malang, 2012
L. Tanya, Bernard, et. al. 2007. Teori Hukum

Strategi Tertib Manusia Lintas Ruang dan Generasi, CV. Kita Surabaya.

Soekanto, Soerjono. 1986. Mengenal Sosiologi Hukum. Alumni. Bandung

Wijaya, Andi Rivai, 2014, Buku Pintar Pemasyarakatan, Lembaga kajiaan Pemasyarakatan

\section{Peraturan Perundang-undangan :}

Undang-undang Republik Indonesia Nomor 12 tahun 1995 tentang Pemasyarakatan.

Undang-Undang RI Nomor 11 Tahun 2012 tentang Sistem Peradilan Pidana Anak

Peraturan Pemerintah Republik Indonesia Nomor 99 Tahun 2012 tentang Perubahan Kedua atas Peraturan Pemerintah Nomor 32 Tahun 1999, dan Peraturan Pemerintah Nomor 28 Tahun 2006 tentang Perubahan pertama atas Peraturan Pemerintah 32 Tahun 1999 tentang Tata Cara Pelaksanaan Hak Warga Binaan Pemasayarakatan.

Peraturan Pemerintah Republik Indonesia Nomor 31 Tahun 1999 tentang Pembinaan dan Pembimbingan

Peraturan Menteri Hukum Dan Hak Asasi Manusia Republik Indonesia Nomor 10 Tahun 2020 Tentang Syarat Pemberian Asimilasi Dan Hak Integrasi Bagi Narapidana Dan Anak Dalam Rangka Pencegahan Dan Penanggulangan Penyebaran Covid-19;

Peraturan Menteri Hukum dan HAM Republik Indonesia Nomor 18 Tahun 2019 tentang Perubahan Peraturan Menteri Hukum dan HAM Republik Indonesia Nomor 03 Tahun 2018 tentang Syarat dan tata Cara Pemberian Remisi, Asimilasi, Cuti Mengunjungi Keluarga, Pembebasan Bersyarat, Cuti Menjelang Bebas, dan Cuti Bersyarat.

Peraturan Menteri Hukum dan Hak Asasi Manusia RI Nomor : 41 Tahun 2017 Tentang Pelaksanaan Jabatan Fungsional Pembimbing Kemasyarakatan.

Peraturan Menteri Pendayagunaan Aparatur Negara dan Reformasi Birokrasi Nomor 
22 Tahun 2016 tentang Jabatan

Fungsional

Kemasyarakatan.

Keputusan Menteri Hukum Dan Hak Asasi

Manusia Republik Indonesia Nomor

M.HH-19.PK.01.04.04 Tahun 2020

Tentang Pengeluaran dan Pembebasan

Narapidana dan Anak melalui Asimilasi

dan Integrasi Dalam Rangka

Pencegahan dan Penanggulangan

Penyebaran Covid-19.

Keputusan Direktur Jenderal Pemasyarakatan

Nomor : PAS-208. PK.01.05.10 Tahun

2016 tentang Pedoman Umum

Pengawasan Klien Pemasyarakatan.

Instruksi Direktur Jenderal Pemasyarakatan

Nomor: PAS-08.OT.02.02 Tahun 2020

tanggal 17 Maret 2020 tentang

Pencegahan, Penanganan, Pengendalian

dan Pemulihan COVID-19 pada Unit

Pelaksanaan Teknis Pemasyarakatan.

Surat Edaran Direktur Jenderal Pemasyarakatan

Nomor PAS-516. PK.01.04.06 Tahun

2020 Tentang Mekanisme Pelaksanaan

Peraturan Menteri Hukum Dan Hak

Asasi Manusia Nomor 10 Tahun 2020

Tentang Syarat Pemberian Asimilasi

Dan Hak Integrasi Bagi Narapidana Dan

Anak Dalam Rangka Pencegahan Dan

Penanggulangan Penyebaran Covid-19.

Surat Edaran Direktur Jenderal Pemasyarakatan

Nomor: PAS.497.PK.01.04.04 Tahun

2020 tanggal 31 Maret 2020 tentang

Pengeluaran dan Pembebasan

Narapidana dan Anak melalui Asimilasi

dan Integrasi dalam rangka Pencegahan

dan Penanggulangan Penyebaran Covid-

19.

Surat Edaran Direktur Jenderal Pemasyarakatan

Nomor: PAS.20.PR.01.01 Tahun 2020

tanggal 26 Maret 2020 tentang Langkah

Progresif dalam Penanggulangan

Penyebaran COVID-10 pada UPT

Pemasyarakatan.

Surat Perintah Direktur Jenderal

Pemasyarakatan Nomor:

PAS.KP.04.01.69 tanggal 9 April 2020.

\section{Makalah}

Poerwanti Hadi Pratiwi, Asimilasi Dan Akulturasi: Sebuah Tinjauan Konsep, staffnew.uny.ac.id/.../asimilasiakulturasi

Rahardjo, Satjipto, Paradigma Hukum Indonesia,Perpektif Sejarah, disampaikan dalam simposium nasional Ilmu Hukum Program Doktor, UNDIP, Semarang, 1998

Subdit Bimbingan Pengawasan. 2014. "Standar Bimbingan Kemasyarakatan". Dalam Forum Group Discussion tanggal 15-17 April 2014. Direktorat Jenderal Pemasyarakatan.

Wordpress. 2012. "Perilaku Pidana Dalam Kajian Sosiologi” Dalam Jurnal Ilmiah. 